\title{
The long-term effects of the Amoco Cadiz oil spill $\dagger$
}

\author{
By G. Conan \\ Centre Océanologique de Bretagne (C.N.E.X.O.), B.P. 337, 29273 Brest Cedex, France
}

- The supertanker Amoco Cadiz wrecked on the coast of northern Brittany in April 1978. The resulting spill of $223000 \mathrm{t}$ of crude oil polluted some $360 \mathrm{~km}$ of rocky or sandy shores, salt marshes and estuaries.

An immediate mortality impact was observed. Populations of bivalves, periwinkles, limpets, peracarid crustaceans, heart urchins and sea birds were the most severely affected. Populations of polychaete worms, large crustaceans and coastal fishes were less affected. Three to six generations $(5-10$ years for bivalves but up to 60 years for birds) may be necessary before populations retrieve their stable age distribution.

Delayed effects on mortality, growth and recruitment were still observed up to 3 years after the spill. Estuarine flat fishes and mullets had reduced growth, fecundity and recruitment; they were affected by fin rot disease. Populations of clams and nematodes in the meiofauna declined one year after the spill. Weathered oil is still present in low-energy areas.

Species with short life cycles tend to replace long-lived species. A fauna of cirratulid and capitellid polychaete worms now prevails in sandy to muddy areas. For several clam populations, recruitment remains unstable. Three years after the spill it is still premature to decide how long it will take before populations and ecosystems reach their former or new equilibria. -

\section{INTRODUCTION}

On the night of 16/17 March 1978, the supertanker Amoco Cadiz was wrecked $2.8 \mathrm{~km}$ from the shore of Portsall, northern Brittany (figure 1). Within the next 2 weeks, most of the $223000 \mathrm{t}$ cargo of Iranian and Arabian crude oil was spilled into the sea. The crude oil was light, it had a low viscosity and contained $30-35 \%$ of highly toxic aromatic hydrocarbons. Very rough sea conditions enhanced the mixing of the oil in sea water by emulsion and dissolution. The volatile compounds, some $40 \%$ of the oil, evaporated rapidly within a few days.

During the first 2 weeks westerly winds blew the spill towards the east. The oil reached Aber Benoît and Aber Wrac'h by 19 March, the Bay of Lannion by 21 March, the Sept Îles bird sanctuary by $22 \mathrm{March}$ and Sillon du Talbert by 23 March. After 2 April, easterly winds blew the spill towards Ushant Island (11 April) and Douarnenez (22 April). About $360 \mathrm{~km}$ of coastline with rocky shores, sandy beaches, salt marshes and estuaries were polluted. The strong tidal ranges $(5-9 \mathrm{~m})$ allowed direct deposition of oil on a wide intertidal strand.

Freshly released oil contained $39 \%$ saturated hydrocarbons, $34 \%$ aromatics, $24 \%$ polar material and $3 \%$ residuals (Calder \& Boehm $198 \mathrm{r}$ ). Linear alkanes ranged from $n-\mathrm{C}_{8}$ to $n-\mathrm{C}_{37}$, but $n-\mathrm{C}_{11}$ was the most abundant. Isoprenoid hydrocarbons phytane and pristane were also found. The aromatic compounds were methylated derivaties of benzene, mostly of naphthalene and to a lesser extent of phenanthrene. Small amounts of dibenzothiophene derivatives were also present. More than 300 compounds, present in fresh crude oil, evolved differently under heterogeneous environmental conditions of temperature, oxygen, light and sea water 
turbulence. It has been suggested that locally, in shallow water under strong light conditions, derivatives related to pesticides could have been formed during the weathering process (Laseter, personal communication).

In terms of ecological time the Amoco Cadiz oil spill is still a recent event, and it is rather premature to draw definite conclusions about its long-term ecological effects. However, quite

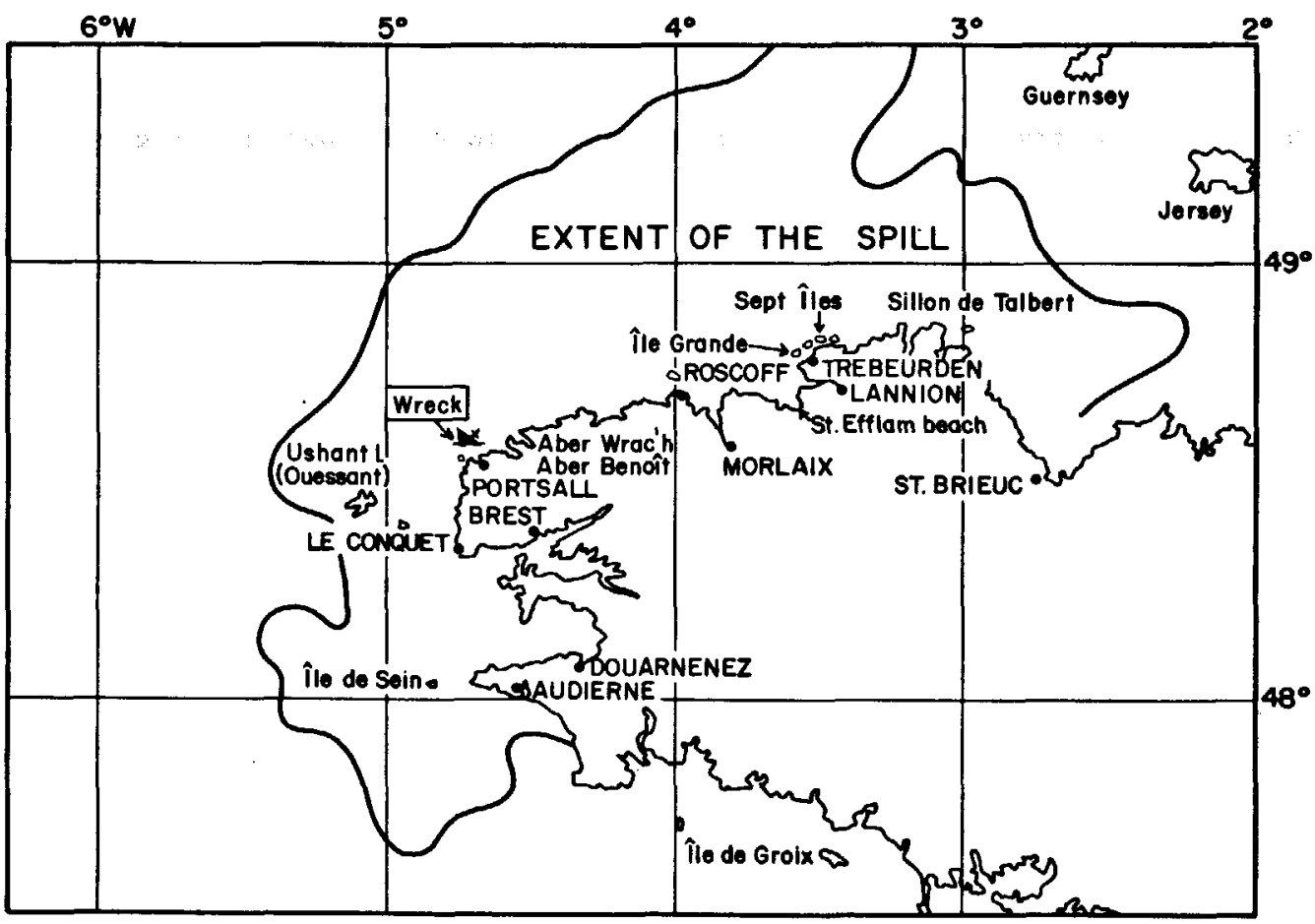

Figure 1. Map of Brittany showing the maximal extent of the Amoco Cadiz oil spill.

a few inferences can be made. The long-term effects may result from (1) demographic imbalance due to the immediate mortality impact on populations, eventually resulting in community shifts, and (2) delayed impact on populations that had apparently well withstood the spill in the short term.

\section{The IMMEDIATE MORTALITY AND ITS LONG-TERM CONSEQUENGES}

During the first week after the wreck, a very heavy mortality affected the intertidal and subtidal fauna. Little is known about the physiological reasons for these deaths, although acute poisoning by the aromatic compounds or their derivatives is usually stated. Dead fish, crustaceans, molluscs and heart urchins were stranded along the shore. Bivalves and polychaete worms in the intertidal zone appeared anaesthetized, and apparently did not react to predation. Highest mortalities were produced in a $5 \mathrm{~km}$ radius around the wreck, and in distant places where the oil was blown and accumulated ashore by the wind: Aber Benoit, Aber Wrac'h, Roscoff, Trebeurden, St Efflam.

Most of the estimates of numbers of dead animals were made by students and staff from the 
Université de Bretagne Occidentale at Brest. At St Efflam $10^{6}$ heart urchins (Echinocardium cordatum), $7.5 \times 10^{6}$ cockles (Cardium edule) and 7.0 $\times 10^{6}$ other bivalves (Solenidae, Mactridae, Veneridae) were found dead. About $10^{4}$ dead fish, mainly wrasses (Labridae), sand eels (Ammodytes spp.) and pipe fishes (Syngnathidae), as well as large crustaceans (Cancer pagurus, Portunus puber, Carcinus maenas) and shrimps (Crangon crangon, Leander serratus) were found within a radius of $10 \mathrm{~km}$ around the wreck.

Chasse ( 1980 ) estimated that on rocky intertidal strips the herbivorous gastropods (periwinkles and limpets) were the most severely affected species. The genera Littorina, Gibbula and Monodonta experienced $54 \%$ loss in numbers, the limpets (Patella spp.) $30 \%$ loss. The fauna living beneath the boulders was greatly affected. The amphipods vanished almost completely, while few isopods and crabs (Carcinus maenas) were left. The subtidal fauna of ascidians, sponges, hydroids, crustaceans and sea stars apparently remained in good state. There is no evidence of a severe direct impact of oil pollution on any intertidal or subtidal species of algae. Locally, however, the intertidal algae were tarred or oiled but most of them recovered.

In low-energy sandy or muddy shores and bays, both the subtidal and the intertidal fauna were strongly affected. The impact, however, was extremely variable, even in places faunistically similar. In the intertidal zone, most species of clams (Solenidae, Mactridae, Veneridae) the epipsammic crustaceans (Mysidaceae, Crangonidae) and the heart urchin were depleted. Even polychaete worms such as Nereis diversicolor, Arenicola marina and Audouinia tentaculata, which were later found to withstand the oil best, collapsed. In the subtidal zone the peracarid crustaceans Apseudes sp., Ampelisca spp., Bathyporeia sp., Urothoe sp. and the heart urchin almost vanished. There is evidence that two species of Ampelisca were completely destroyed in Bay of Morlaix (Dauvin, personal communication). The harpacticoid copepods and the nematodes of the meiofauna were little or not affected in Bay of Morlaix (Boucher 198I), although in the low-energy Morlaix estuary a limited impact was observed on turbellarian worms and harpacticoid copepods (Renaud-Mornant et al. 198I).

Numerous dead tarred sea birds were found in the strand. Although it was estimated that between 15000 and 20000 sea birds died, the impact (0.1 bird per tonne of oil) was low when compared with previous experiences. The Alcidae family was the most heavily stressed. Many dead birds were non-indigeneous migrating individuals with nesting colonies in the British Isles (Monnat 1978, personal communication).

If one excepts the two Ampelisca species, there is limited evidence that any animal or vegetable species was completely destroyed by the immediate impact of the spill in the area. Population recovery will depend on the life strategy of each species. The life expectancy, the fecundity and the ecology of larvae, either planktonic or benthic, will determine how soon a species may recover in terms of stable age distribution and density. A full recovery cannot be achieved before several generation times. In the mean while, species with high fecundity, a short life cycle and efficient means of dispersion for their larvae (species with planktonic stages) will tend to occupy the space left by species with a long life cycle or low colonizing efficiency, such as peracarid crustaceans (Ampelisca), which have no planktonic larval stages.

As to the vanished Ampelisca populations, although the life cycle is short (1-2 years life expectancies and several spawnings per year) there are no known settlements of the same species on the north coast of Brittany and it may take many years before adults may come from neighbouring locations in southern Brittany or Normandy. Species of clams and fishes have life expectancies of 5-10 years, and one would expect as much as 30 years or 3-6 generations 
for a complete recovery of a stable age distribution. Seabirds have life expectancies of up to 20 years and an isolated population may need up to 60 years for its recovery under stable environmental conditions. The puffins were already experiencing negative trends in population density, and these trends were enhanced by the spill. At the Sept Illes sanctuary about 2000 pairs were present in 1950, while recent censuses indicate almost a point of no return for the population: 150 pairs (Monnat, personal communication).
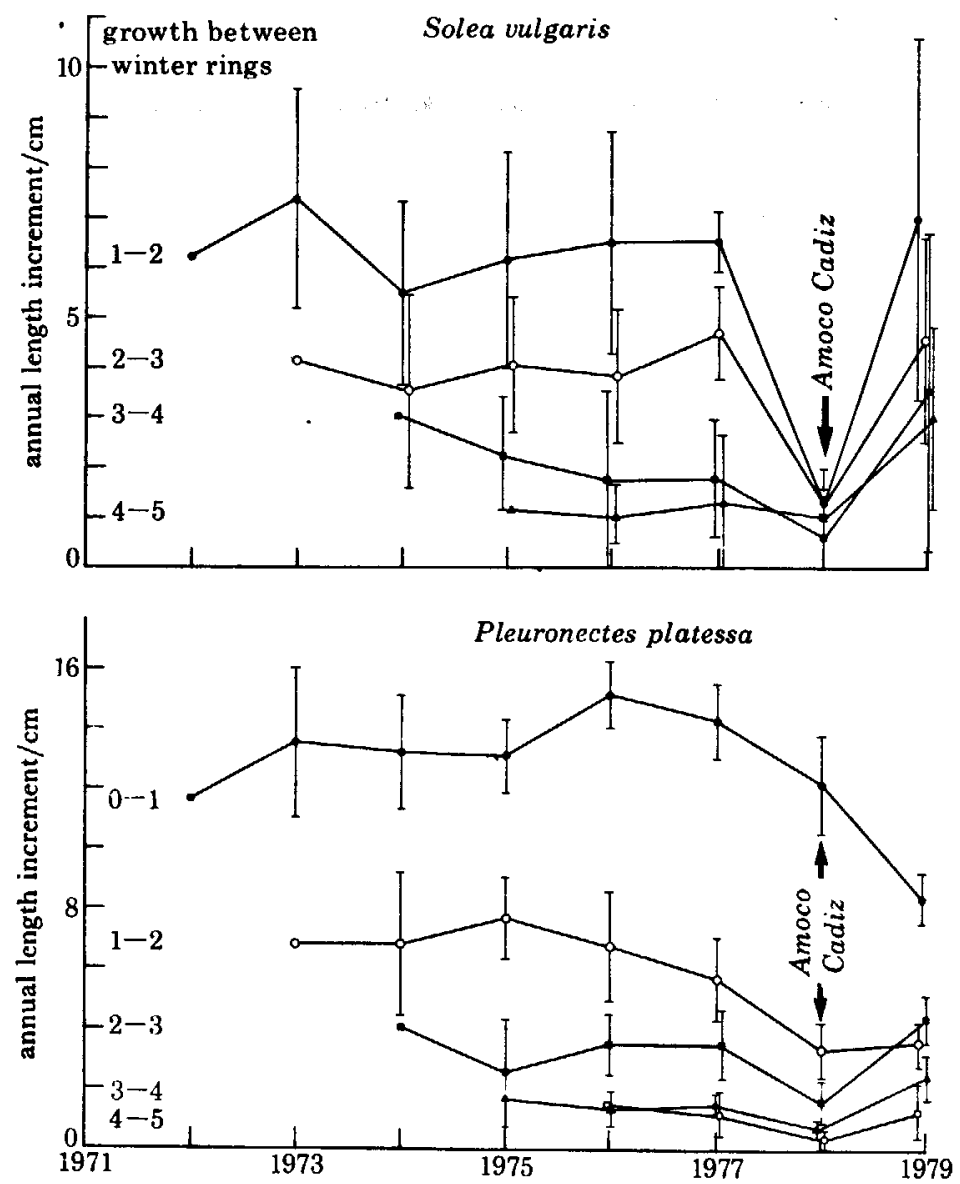

Figure 2. Standard length increments between formation of winter rings on otoliths of sole and plaice before the spill $(19727)$ and after the spill $(1978-9)$. Confidence limits $(95 \%)$ are set on the means. A drop in growth rate is observed after the spill.

If the effects of the oil spill had been restricted to an immediate mortality impact, populations and communities would have been expected to recover after a time lag of a few years. However, it now appears that delayed effects on population variables of many species were still experienced $2-3$ years after the spill.

\section{THE DELAYED EFFECTS AND THEIR LONG-TERM CONSEQUENGES}

The delayed effect of the oil spill are more difficult to demonstrate than the direct mortality impact. The reasons are that populations and ecosystems naturally fluctuate in time so that 
significant departure from natural trends or cycles in, say, growth, mortality or recruitment are frequently controversial. Ideally one would need either information over long time series or control populations and communities not affected by pollution. Both types of approaches have been attempted for evaluating the delayed effects of the spill.

Conan \& Friha (198I) used growth ring readings on otoliths to estimate growth of sole and plaice 2-6 years before the spill. They found that in the Aber-Benoit estuary all age groups

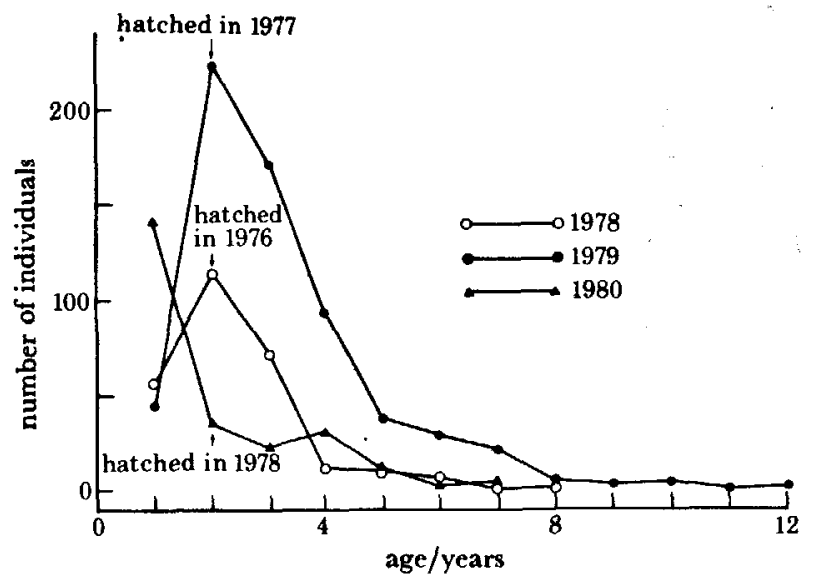

Figure 3. Catch curves for plaice caught in Aber Benoit during biological ycars delimited by winter ring formation on otoliths. In 1978 and 1979 , the smoothness of the right limb of the curves indicates a very stable recruitment before the spill. In 1980, an abnormally low relative abundance of age classes 2 and 3 (fish hatched in 1978 and one year old in 1978) is observed.

had growth rates significantly smaller in 1978 than in previous years (Kruskal-Wallis tests: sole, $p$ ranging from 0.00 to 0.01 for age classes $1-4$; plaice, $p$ ranging from 0.02 to 0.03 ). In 1979 growth rates were back within their usual range in most cases (figure 2). Lamrini (r980) obtained similar results for three species of mullet in the same location. The spill had apparently no effect, however, on the growth of the clam, Tellina tenuis, at the heavily polluted beach of St Efflam (Conan \& Guenole, unpublished).

Chasse (personal communication) estimates that as a whole delayed mortality effects on sand and mud biotas were 1.4 times as large as immediate effects. At the St Efflam beach Tellina fabula started to disappear from the intertidal zone a few months after the spill, it is now strictly restricted to subtidal levels. The closely related species $T$. tenuis, however, appeared to have mortality rates lower than usual, possibly due to a lack of predators. In the Bay of Morlaix nematode densities in the meiofauna had been fairly stable from 1973 to 1978 , but they started to slowly decline months after the spill (Boucher, personal communication). Friha \& Conan (1981) estimated that the mortality rates of plaice in the Aber-Benoit estuary were higher in 1978 and 1979 than in previous years, although these differences were not significant in all cases.

Miossec (198I) has shown that fecundity of plaice in the Aber-Benoit and Wrac'h estuaries was severely impaired when compared with observations from previous years or control sites (Baie of Douarnenez). Lamrini (1980) states similar results for mullet in the same location. Lopez et al. (1981) indicate that a complete degeneration of many oocytes is observed in the ovaries of eels. 
Observations on the recruitment of plaice by Conan \& Friha (figure 3) and by Miossec (1981) show that, in the Abers, the age class hatched in 1978 was far less numerous than usual. It can be inferred from the smooth catch curve of old age groups that in the years preceding the spill the recruitment and age distribution in the population had been extremely stable. At $\mathrm{St}$ Efflam beach, three species of bivalves were very abundant in the intertidal zone before the

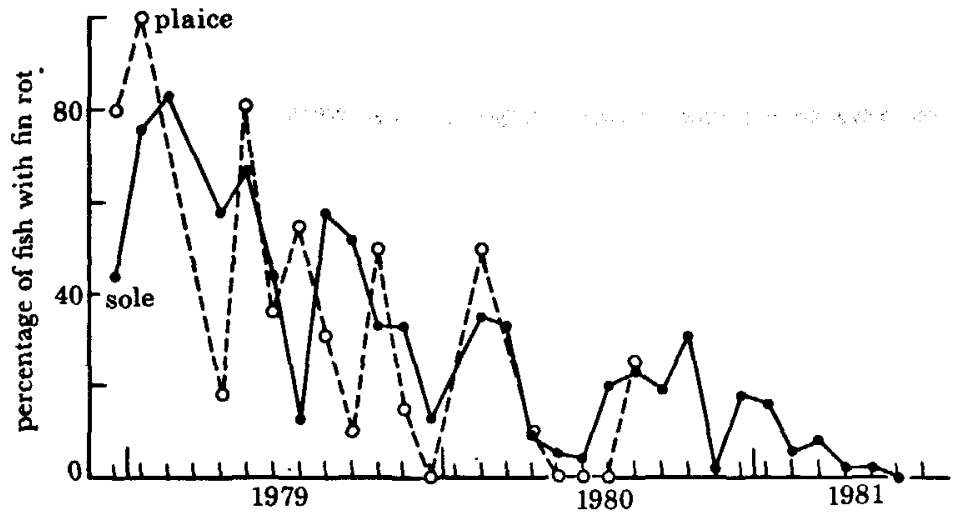

Figure 4. Variation over time of the percentage of fish bearing fin rot desease in Aber Benoît. A negative trend is observed between 1978 and 1979 , both for sole and plaice.

spill: Tellina tenuis, Tellina fabula and Donax vittatus. In 1978 the recruitment was nil for $D$. vittatus, very slight for $T$. fabula and almost normal for $T$. tenuis. In 1979, the recruitment was fairly important although unstable in time for $D$. vittatus, nil for $T$. fabula and almost normal for $T$. tenuis (Conan and Guenole, unpublished).

Fin rot disease as a consequence of the spill has been reported for several species of fish (mainly plaice, sole and mullet) by Miossec (198I), Conan \& Friha (1979, r98I), Desaunay (I98I) and Lamrini (1980). The proportions of fish with fin rot decreased from $80 \%$ in 1978 to almost nil in 1981 (figure 4).

Weathered derivatives of the oil are still present in a few low-energy sandy and muddy places (salt marshes, estuaries and beaches). A definite layer of buried oil is still present on many beaches, it is thought to migrate downward (Long et al. 1981). In some beaches in the Abers and in salt marshes of Île Grande, a film of weathered oil appears to have stabilized on the surface of the water table. Sheen can still be seen to come out of the sediment in some places at rising tide. These hydrocarbons, however, would consist of stable compounds no longer degradable by microorganisms and presumably have little effect on the environment (PlanteCuny, personal communication).

Long-term geomorphological effects have been reported (Plante-Cuny and Levasseur, personal communications). At the salt marshes of île Grande, in places where the vegetation cover has been to a large extent destroyed by the oil, it appears that the ooze is still being eroded away by the sea. Such damage seems to be irreversible.

These various examples show that even in 1981 the biological environment has not returned to its pristine condition and that the recovery of populations and communities is not a simple matter of demography and species interactions. Many individuals of species with long life expectancies (birds, fish and bivalves) are probably still physiologically affected. 


\section{GENERAL OBSERVATIONS AND INFERENCES ON LONG-TERM ECOSYSTEM AND POPULATION EFFECTS}

In the long term it appears that the most severely affected biotas are low-energy sandy and muddy shores, bays and estuaries and salt marshes such as the beach of St Efflam, the Bay of Morlaix at Pierres Noires, the Aber-Benoit and Aber-Wrac'h estuaries and the Île Grande salt marsh.

In such places populations of certain species with long-term or short-term life expectancies have either vanished or are still declining (heart urchin, Tellina fabula at St Efflam, two Ampelisca

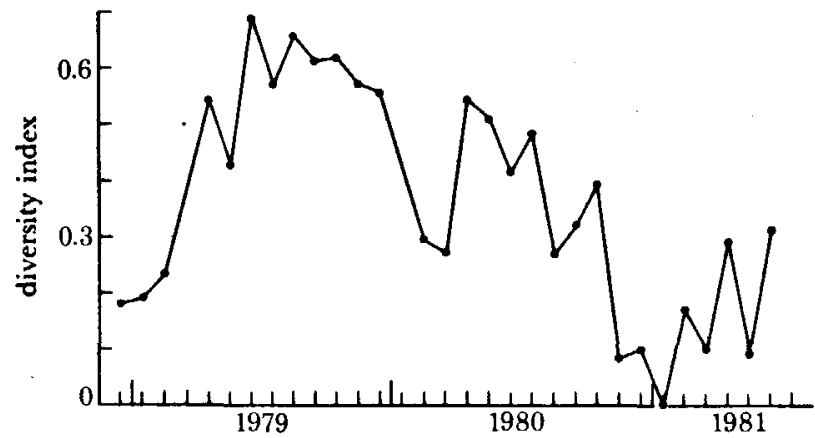

Frgure 5. Variation over time of a diversity index (proportion of interspecific encounters) for flat fish in Aber Benoît. Apart from seasonal fluctuations, a slight negative trend may prevail after summer 1979 .

species at Pierres Noires, nematodes in many places, and Juncus maritimus in the vegetation of Île Grande), while others develop rapidly (Nephtys hombergi at St Efflam, Ampelisca sarsii at Pierres Noires, cirratulid and capitellid polychaete worms in most places, and Halimione portulacoides in the vegetation of Île Grande). For several species of bivalves at St Efflam (Donax vittatus, Pharus legumen and Tellina fabula), recruitment varies greatly from year to year; this may be a consequence of an unstable age distribution in the parental population.

At the ecosystem level it appears that the former species assemblages have evolved. The fauna is reported to be related in its species composition to what is encountered in chronically polluted areas close to harbours or sewer outfalls. New equilibrium stages have not yet been reached in many affected areas and several species still develop actively. At Pierres Noires, however, it appears that an equilibrium has been reached, the remaining species behave well, the biomass being stable and similar to what it was before the pollution, although the number of individuals per unit area is lower.

Several diversity indices have been used to follow the evolution over time of the species assemblages. Species richness of the benthos is reported to be stable at Pierres Noires and to be increasing in Morlaix estuary (Dauvin, personal communication). As to meiofauna, the Shanon-Weaver index decreased, while the Corbet-Williams index first increased and then decreased. It is difficult to draw any general conclusions concerning diversity, owing to the various indices used. For flat fish fauna in the Abers we have used the proportion of potential interindividual interspecific encounters, as recommended by Hurlbert (1971). According to this index, a slight decrease in diversity (figure 5) may prevail, although most of the fluctuations appear to be seasonal. Following Pearson \& Rosenberg ( 1978 ), it seems that the most synthetic 
and efficient way of surveying the long-term impact of an oil spill on an ecosystem would be to assess simultaneously its changes in species richness, biomass and abundance through time.

As a general conclusion, it is rather premature to decide whether the ecosystems and populations of the impacted areas will ever regain their original state, and it is also premature to give precise indications on how long it will take before the new or the former stable age distributions and equilibrium species assemblages will be attained. There are already several indications that populations and ecosystems have been affected on a long-term scale. It seems unlikely that the oil spill impact will remain within the range of 'natural' random fluctuations due to other environmental physical factors. An extensive long-term ecological survey needs to be conducted. Such a survey is now being financed by the French Government.

I thank the following persons for the unpublished information they made available for the preparation of this paper: Dr C. Chasse and Dr J. Y. Monnat (Université de Bretagne Occidentale), Dr G. Boucher and Dr J. C. Dauvin (Station Biologique de Roscoff), Dr M. R. Plante-Cuny (Station Marine d'Endoume), Dr J. Levasseur (Faculté des Sciences Biologiques, Rennes), Dr R. Kaas (Institut Scientifique et Technique des Pêches Maritimes) and Dr J. L. Laseter (Center for Bio-organic studies, University of New Orleans). I also thank Dr L. Laubier (Centre National pour l'Exploitation des Océans) for his constructive criticisms while reviewing this paper.

\section{REFERENCES}

Boucher, G. 198 I Effets à long terme des hydrocarbures de l'Amoco Cadiz sur la structure des communautés de Nématodes libres des sables fins sublittoraux. In Amoco Cadiz, fates and effects of the oil spill (ed. G. Conan, L. Laubier, M. Marchand \& L. d'Ozouville), pp. 539-549. Paris: C.N.E.X.O.

Calder, J. A. \& Boehm, P. D. 1981 The chemistry of Amoco Cadiz oil in the Aber Wrac'h. In Amoco Cadiz, fates and effects of the oil spill (ed. G. Conan, L. Laubier, M. Marchand \& L. d'Ozouville), pp. 149-158. Paris: C.N.E.X.O.

Chasse, C. 1980 Les leçons d'un bilan écologique modéré, quoique coûteux et menaçant. In Impact socio-économique de la marée noire provenant de l'Amoco Cadiz (ed. F. Bonnieux, P. Dauce \& P. Rainelli), pp. 74-92. Rennes: Rapport UVIOE-INRA.

Conan, G. \& Friha, M. 1979 Impact des pollutions par hydrocarbures de l'Amoco Cadiz sur la croissance des soles et des plies dans les Abers du Nord de la Bretagne. (ICES C.M. 1979/E:54) Marine Environment Quality Committee.

Conan, G. \& Friha, M. 198 I Effets des pollutions par hydrocarbures du pétrolier Amoco Cadiz sur la croissance des soles et des plies dans l'estuaire de l'Aber Benoit. In Amoco Cadiz, fates and effects of the oll spill (ed. G. Conan, L. Laubier, M. Marchand \& L. d'Ozouville), pp. 749-774. Paris: C.N.E.X.O.

Desaunay, Y. ${ }_{1981}$ Evolution des stocks de poissons plats dans la région contaminée par l'Amoco Cadiz. In Amoco Cadiz, fates and effects of the oil spill (ed. G. Conan, L. Laubier, M. Marchand \& L. d'Ozouville), pp. 727-736. Paris: C.N.E.X.O.

Friha, M. \& Conan, G. 1981 Long-term impact of hydrocarbon pollution from the Amoco Cadiz on the mortality of plaices (Pleuronectes platessa) in the Aber Benoit estuary. (ICES C.M. 1981/E:85.) Marine Environment Quality Committee.

Hurlbert, S. H. 1971 The non concept of species diversity: a critique and alternative parameters. Ecology 52, 577-586.

Lamrini, A. 1981 Contribution à l'étude de l'impact de la maré noire de l' Amoco Cadiz sur les populations de mulets (Chelone labrosus, Mugil auratus, Mugil ramada). Mémoire DEA, Océanogr. biol., Brest.

Long, B. F., Vandermeulen, J. H. \& Buckley, D. E. I98I Les processus de la migration du pétrole échoué dans les estrans sableux: contamination des nappes phréatiques. In Amoco Cadiz, fates and effects of the oil spill (ed. G. Conan, L. Laubier, M. Marchand \& L. d'Ozouville), pp. 79 94. Paris: C.N.E.X.O.

Lopez, E., Leloup-Hatey, J., Hardy, A., Lallier, F., Martelly, F., Oudot, J., Peignoux-Deville, J. \& Fontaine, Y. A. 1981 Modifications histopathologiques et stress chez des anguilles soumises à une exposition prolongée aux hydrocarbures. In Amoco Cadiz, fates and effects of the oil spill (ed. G. Conan, L. Laubier, M. Marchand \& L. d'Ozoubille), pp. 737-748. Paris: C.N.E.X.O. 
Miossec, L. I981 Effets de la pollution de l'Amoco Cadiz sur la morphologie et sur la reproduction des plies (Pleuronectes platessa) dans l'Aber Wrac'h et l'Aber Benoit. In Amoco Cadiz, fates and effects of the oil spill (ed. G. Conan, L. Laubier, M. Marchand \& L. d'Ozouville), Pp. 737 748. Paris: C.N.E.X.O.

Monnat, J. Y. 1978 Effet du pétrole de l'Amoco Cadiz sur les oiseaux de mer. Bilan provisoire. In Amoco Cadiz, premières observations sur la pollution par les hydrocarbures (ed. G. Conan, M. Marchand \& L. d'Ozouville), pp. 135-142. Paris: C.N.E.X.O.

Pearson, T. H. \& Rosenberg, R. 1978 Macrobenthic succession in relation to organic enrichment and pollution of the marine environment. A. Rev. Oceanogr. mar. Biol. 16, 229-311.

Renaud-Mornant, J., Gourbault, N., de Panafieu, J. B. \& Helleouet, M. N. i 98 i Effets de la pollution par hydrocarbures sur la méiofaune de la Baie de Morlaix. In Amoco Cadiz, fates and effects of the oil spill (ed. G. Conan, L. Laubier, M. Marchand \& L. d'Ozouville), pp. 551-561. Paris: C.N.E.X.O.

\section{Discussion}

G. M. Dunnet (Zoology Department, University of Aberdeen, U.K.). It was stated that the recruitment of clams to beaches affected by the oil spill was variable but in general reduced. Was this reduction in the settlement of larvae due to the persisting unsuitability of the substrata provided by the beaches or to the lack of larvae? If the latter, is anything known about the duration of the mobile larval stages in different species of clams, and the distances over which they can be transported before settling?

G. Conan. In the locations where data are available over long enough periods, such as the beach of St Efflam, it appears that annual recruitment for bivalve species such as Donax vittatus, Tellina fabula and Tellina tenuis has remained unstable during the 3 years since to the spill. After the spill, the amount of settling larvae greatly varied from year to year. A survey of age distributions in collections of shells tends to demonstrate that before the spill such settlements were fairly stable from year to year. For some species such as Tellina fabula, the larvae that eventually settled in the intertidal after the spill did not survive their first year of life. Both the abundance of the settling larvae and later their survival at early benthic stages were affected.

The scarcity of settling larvae may not be directly related to the availability of a parental stock in the vicinity. Oil spill-induced mortality of adults was highly variable even over short distances. There is no evidence for a complete disappearance of any bivalve species in the affected area. I have no precise information on how long the larvae of affected bivalve species may remain in the plankton, although 3-4 weeks of planktonic life are common for commercial species raised in aquaculture projects. Random variability in abundance of recruitment is likely to increase with the distance of the parental stock to the settling beds and with the patchiness of the distribution of the parental stocks.

I would tend to interprete the enhancement of year to year fluctuations in abundance of settling larvae as being a consequence of $(1)$ an increased patchiness of the parental stock and (2) an unbalanced age distribution within the parental stocks, both factors resulting from the spill.

D. J. CRIsP, F.R.S. (Marine Science Laboratories, Menai Bridge, U.K.). Dr Conan suggested that the cause of death of polychaetes in heavily oiled sand was perhaps the aromatic fraction of the crude oil. Measurements of acute toxicity on the activity scale do not indicate a wide disparity between aromatic and aliphatic short-chain compounds. Either would be lethal at saturation and sufficient to explain mass mortality by acute physical toxicity when unweathered crude oil was intimately mixed with sea water. 
G. Conan. On the basis of laboratory experiments, it has frequently been stated that aromatic hydrocarbons were responsible for most of the toxicity of crude oil. Aliphatic short-chain hydrocarbons are also described as potentially toxic on the same basis. To my knowledge, however, there is little information on the chemical characteristics of the compounds that were actually responsible for the heavy mortalities experienced by polychaete worms, periwinkles, bivalves and many other organisms within a few days after the wreck.

The composition of crude oil changes fairly rapidly under natural environmental conditions. Under the very heterogeneous conditions that prevail in coastal waters the chemistry of the weathering of the numerous compounds already present in fresh crude oil is not well known. The effects of such compounds on the physiology of marine invertebrates is not, well known either.

Curiously, mass mortality was not necessarily correlated with conspicuous concentrations of oil. In places such as the west side of St Efflam beach, only sheen was noticeable, yet the oil acted very efficiently in killing most of the invertebrate fauna. Close to Portsall, polychaete worms and limpets survived in several places where a thick layer of oil had reached the shore. Mass mortality is likely to be explained by the presence of certain derivatives of crude oil compounds, even in slight concentrations, rather than by heavy concentrations of total hydrocarbons.

D. J. CRISP. There is a widely held opinion that the micro-growth bands in bivalves are laid down daily. By marking bands so that their exact date of formation is known we have demonstrated that in all intertidal bivalves (as well as barnacles and gastropods) studied, bands are formed on each tidal emersion, and hence at the rate of approximately two per day. Therefore, if the conclusion that oil pollution had no influence on bivalve growth were based on back counting of bands to those supposedly formed at the time of the Amoco Cadiz increment, it is possible that the wrong part of the shell was inspected if the banding was assumed to be at daily rather than tidal intervals. Bivalves can evade uptake of pollutants by closing the valves, but survival would then be at the expense of feeding and the event ought to show as diminished increments in the micro-growth bands.

G. Conan. The effects of oil pollution on the growth of bivalves were studied by two methods: macroscopic ring reading and micro-ring reading.

1. Macroscopic growth rings are formed annually on shells of Tellina tenuis or Donax vittatus; additional spawning rings are sometimes present but easily recognizable. The age-specific growth increments in shell height varied from year to year and according to the location on the beach. No special departure of growth from its usual annual or geographic fluctuations was found in 1978, the year of the wreck.

2. An acetate print of a polished and acid-etched shell cut is made. An enlarged picture of this print is obtained from microphotographs. The distances between micro-rings are measured after digitizing the coordinates of each micro-ring on a digitizing table connected to a computer. A growth curve representing the height of the shell as a function of the number of rings is plotted by the computer. This curve is compared visually with an equivalent curve obtained by reading annual macroscopic rings. Apart from seasonal fluctuations of growth, which cannot be obtained from yearly increments, both curves usually conform to similar patterns. Up to now no growth accidents could be attributed to the effects of the oil spill. 
Two types of micro-rings are present on the shells: usually one well marked ring alternates with a faint ring. Only well marked rings were digitized. It was assumed that one day separated each well marked ring from the next. By this assumption, growth curves obtained from micro-ring reading conform with those obtained from macro-ring reading. Nevertheless we cannot decide whether the rings were deposited according to a diurnal or a tidal rhythm. In this part of the Atlantic, during one year, these two types of rhythms would produce sequences differing by only about twelve periods 'or micro-rings out of about 365. The errors due to incorrect ring reading by inadvertantly skipping or adding rings are greater than this difference.

Our results, although established for individual from a species, Tellina tenuis, in a heavily affected area, should not be extrapolated to all bivalves. Dr Vandermeulen has shown by similar methods, under different circumstances, that the growth of Mya arenaria could be strongly affected by an oil spill. 
Achevé d'imprimer

en Mai 1983

par INSTAPRINT - TOURS 



\section{Série "Recueil des Travaux du Centre Océanologique de Bretagne"}

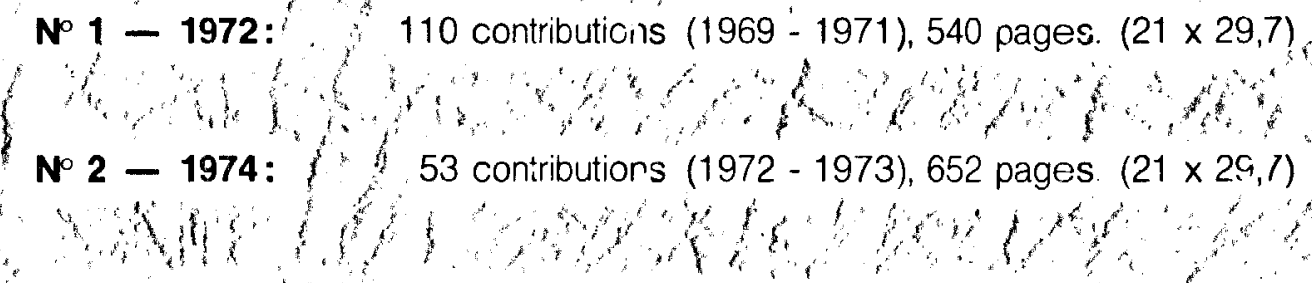

No $3-1975:$

No $4-1976$ :

No $5-1977:$

№ $6-1978:$

No $7-1979:$

№ $8-1980$ :

№ $9-1981:$

No 10 - 1982:
68 contributions (1973-1974), 725 pages. $(2 i \times 29.7)$

65 contributions $(1974-1975), 710$ pages. $(21 \times 29,7)$

40 contributions $(1975-1976), 545$ pages. $(21 \times 29,7)$

41 contributions $(1976-1977), 529$ pages. $(21 \times 29.7)$ epuisé

.53 contributions $(1977-1978), 742$ pages. $(21 \times 29,7)$ épulsé :

65 contributions (1978 - 1979), 838 pages. $(21 \times 29,7)$

42 contributions (1979 - 1980), 556 pages. $(21 \times 29,7)$

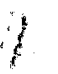

58 contributions $(1980,1981), 588$ pagest $(16 \times 24)$ 